\title{
Caste-based discrimination in Indian hospitals: a blight for youngsters of the 21st century
}

HARISH GUPTA

Keywords: Workplace bullying, caste, India, healthcare, violence

I object to violence because when it appears to do good, the good is only temporary; the evil it does is permanent.

Mahatma Gandhi (Young India, May 21, 1925)

Barua and Verma assess the role of caste in workplace bullying at Indian healthcare facilities in their recent Comment in IJME (1). They examine the possible role of caste in mental violence suffered by trainee doctors. They conclude with a call to address the issue of mental health needs of doctors. It is true that doctors work under tremendous stress, have to make rapid decisions, sometimes consider the death of a patient as a personal failure, and frequently wonder what more could have been done to save a life. I believe that that should not be a pretext to shield habitual offenders of caste-based violence which, sadly, the authors appear to be doing in their Comment. Sylvia Karpagam correctly states that caste-washing the healthcare system will do little to address its discriminatory practices (2).

What I want to make the authors remember is that suicide resulting from caste-based harassment is to be looked at as a continuum. Every year, several students die by suicide for this reason, and this is conveniently dressed up as a mental health issue of the victim (3). The vested interests of the authorities and the desire to bail out their bullying colleagues do not allow them to accept the reality. In the section "The casteismreservation intersection", Barua and Verma write that "the problem of casteism in medical colleges is partly fueled by reservation in entrance examinations". I want to remind them that caste-based discrimination is not a unique pathology of medical institutions. Last year, a report in The Print stated that

Author: Harish Gupta (harishgupta@kgmcindia.edu), Associate Professor, Internal Medicine, KG's Medical University, Chowk, Lucknow, UP, 226003 INDIA

To cite: Gupta H. Caste-based discrimination in Indian hospitals is a blight for youngsters of the 21st century. Indian J Med Ethics. 2021 Jan-Mar; 6(1) NS: 53-54.DOI:10.20529/IJME.2021.009.

(C) Indian Journal of Medical Ethics 2020 of 89 Secretaries in the current Union government, there were just three from the Scheduled Tribes (ST), one from the Scheduled Castes (SC) and none from the Other Backward Classes (OBC) (4).

Another report in the Indian Express last year revealed that just $12.4 \%$ IIT-Madras faculty belong to the reserved category (5). I want to inform the authors that the malady of caste based discrimination is all pervasive and the examples are numerous. This author is privy to conversations with faculty members who have faced slights, innuendo and sometimes plain mockery when they inform their interviewers that they are applying for a reserved seat. There are no prizes for solving the puzzle of vacant faculty seats in these institutes of national importance, when all the facts are laid bare for appraisal.

It is a fact that sometimes undeserving candidates get the benefit of reservation in educational opportunities and jobs. And for that purpose, there is a rule excluding the "creamy layer" in OBC reservations (6). When a candidate keeps on getting the benefit of reservation at more than one level, again there is misuse of scant national resources due to which a more deserving candidate of the same group may be left out (7). But looking through this window, we find that all the laws are misused at some point: for example the SC/ST (Prevention of Atrocities) Act, 1989, the Dowry Prohibition Act, 1961, right to freedom of expression and now even anti-terror laws. But despite misuse, these laws remain in our statute books and constant collective efforts are being made to prevent misuse.

Positive discrimination under caste-based reservation is made to allow oppressed groups to access their rights in a democracy where none exist at baseline. If some individuals deny this opportunity to someone, what sort of healers such persons will amount to needs to be considered. Daily, we examine patients at their most vulnerable times, when they are suffering and desperately seek our help. If someone brings the culture of bullying into that environment, in my opinion he or she is the biggest perpetrator of violence, and has never understood the meaning of the art of medicine. And if the violence is directed towards the most vulnerable person in the hierarchy, who can't even fight back, it is the biggest crime of all. The irony of our times is that such violent actors are seldom, if ever, brought to book!

\section{References}

1. Barua MP, Verma A. Workplace bullying in healthcare: Role of reservation and caste. Indian J Med Ethics. 2021 Jan-Mar;6(1)NS: 44-46. DOI: 10.20529/JJME.2020.107.

2. Karpagam S. Caste-washing the healthcare system will do little to 
address its discriminatory practices. Indian J Med Ethics. 2021 Jan-Mar ; 6(1) NS:47-48. DOI: 10.20529/IJME.2020.108.

3. Joshi S, Desai K. A student commits suicide every hour. Times of India. 2020 Sep 16[cited 2020 Nov 20]. Available from: https:// timesofindia.indiatimes.com/india/a-student-commits-suicide-everyhour-/articleshow/78102907.cms

4. Gupta MD. Of 89 Secretaries in Modi govt, there are just 3 STs, 1 Dalit \& no OBCs. Print.in. 2019 Aug 5[cited 2020 Nov 21]. Available from: https://theprint.in/india/governance/of-89-secretaries-in-modi-govtthere-are-just-3-sts-1-dalit-and-no-obcs/271543/

5. Chaitanya SVK. Just $12.4 \%$ IIT-M Faculty belong to reserved categories. Indian Express. 2019 Jul 10[cited 2020 Nov 21]. Available from: https:// www.newindianexpress.com/states/tamil-nadu/2019/jul/10/just-124iit-m-faculty-belong-to-reserved-categories-2001731.html

6. PTI. OBC quota: Raise creamy layer ceiling, don't count salary, farm income, says parliamentary panel. Economic Times. 2020 Jul 30 [cited 2020 Nov 22]. Available from: https://economictimes.indiatimes.com/ news/politics-and-nation/obc-quota-raise-creamy-layer-ceiling-dontcount-salary-farm-income-says-parliamentary-panel/articleshow/ 77263858.cms?from $=\mathrm{md}$

7. Editorial. Supreme Court judgment on reservations. Econ Pol Wkly. 2020 Feb 15[cited 2020 Nov 20]; 55(7). Available from: https:// www.epw.in/journal/2020/7/editorials/supreme-court-judgmentreservations.htm

\section{APPEAL FOR DONATIONS TO THE FORUM FOR MEDICAL ETHICS SOCIETY}

The Forum for Medical Ethics Society (FMES), publisher of the Indian Journal of Medical Ethics (IJME), appeals to subscribers, contributors, readers, supporters and well-wishers of IJME and FMES to donate to its corpus and towards the publication of IJME. Contributions from both individuals and institutions are welcome.

FMES has published the journal on a shoestring budget, without a break, since 1993. The journal is known for being open access and spearheading discourse aimed at advancing social justice in health and ethics-centred healthcare and health research reform. It is recognised widely as an authoritative resource of knowledge in bioethics and allied areas of enquiry. FMES and IJME have not only sustained themselves but have grown over these past 25 years. Our ever-growing base of readers, contributors, and reviewers enables the publication of multiple and diverse perspectives on wide-ranging topical areas. We have also striven to upgrade the journal technically to keep up with the advances in publishing to widen our reach. This has been possible only because of your steadfast and sustained support.

We are committed to maintaining our editorial independence which is critical to safeguarding the scientific integrity of what we publish. Therefore, wider support from all those who are committed to social justice in health is essential.

FMES is registered under the Societies Registration Act, 1860 (Reg No: Mumbai-218-1995-G.B.B.D.D) and the Bombay Public Trusts Act, 1950 (Reg No: F-17441 Mumbai, 1995), and donations are eligible for tax exemption under Section 80G of the Income Tax Act, 1961

For more details on how to support us, write to admin@ijme.in or visit our website www.ijme.in/subscribe-support/

$$
\begin{aligned}
& \text { SUPPORT OPEN-ACCESS ACADEMIC PUBLICATIONS, } \\
& \text { DONATE TO THE FMES CORPUS FOR THE PUBLICATION OF IJME! }
\end{aligned}
$$

